\title{
Developing Learning Instrument Based on Guided Inquiry Using CRA Sequence To Improve Students' Problem Solving Skill
}

\author{
$1^{\text {st } I z z a t u r ~ R a h m i ~}$ \\ Mathematics Department \\ Universias Negeri Padang \\ Padang, Indonesia \\ izzaturrahmi3@gmail.com
}

\author{
$2^{\text {nd }}$ I Made Arnawa \\ Mathematics Department \\ Universias Negeri Padang \\ Padang, Indonesia \\ arnawa1963@gmail.com
}

\begin{abstract}
This research aims to produce mathematics learning instrument that valid and practical. It is caused by lack of mathematics problem solving students. This type of research was the Research and Development (R\&D). This research developing a learning instrument that includes lesson plan and student's worksheet using Plomp development model. The data collection used questionnaire validity and practicalities. The results of this research are: 1) learning instrument developed has a valid category, 2) the practicalities of the questionnaire response teacher are $88.46 \%$ and the practicalities of student's questionnaire are $85.64 \%$. Based on the research results, it can be concluded that learning instrument developed can be applied in mathematics learning.
\end{abstract}

Keywords-learning instrument, guided inquiry, CRA Sequence, problem solving skill, validity, practicality

\section{INTRODUCTION}

The development of science in the era of globalization is growing very rapidly. Mathematics is a necessary science in facing the challenges of the future. Mathematics is capable to solve everyday problems that developed in the $21 \mathrm{st}$ century [1]. Problem solving is an integral part of mathematics learning so it can't be separated from mathematics [2].

The learning of mathematics begins with an understanding of concepts and then proceeds to solve mathematical problems [3]. Mathematical learning also uses pattern and reasoning in problem solving [4]. But in reality many students have difficulty in solving the problem. The low achievement of student mathematics is evident from the results of the 2015 PISA study. PISA is an international study that assesses literacy achievement in reading, math, and science. This program aims to measure the skills of children in implementing real-life problems. By 2015 Indonesia is ranked 67 out of 75 countries [5].

In line with the results of the 2015 PISA study, the results of problem-solving tests given to 25 students of SMPN 1 IV Koto are still low. Students have difficulty in understanding the problem. Students are also unable to change the matter into a mathematical model. This causes students fail to find solutions of the problems.

One of the causes of low student problem-solving abilities is the inappropriate device used by teachers [6]. According to the observation in the class and interview with mathematics teacher obtained that the learning is still likely to take place in one direction. Generally, the pattern of learning consist of explain the subject matter, give example, provide training, and the end of lesson the teacher give homework. In this way the students tend to be passive and teacher dominate in the classroom. On the other hand, teachers have not used the learning instruments that can facilitate students to construct their own learning. Therefore, teachers should be able to provide good learning tools before learning [7]. Learning instruments should be able to familiarize students to actively solve problems. In addition to providing learning tools, teachers must also be able to choose a model of learning that can improve student's problem solving skills.

One of the lessons that can help students develop their problem-solving skills is guided inquiry learning [8]. Guided inquiry learning provides students with opportunities and experiences to understand concepts and solve problems [9]. Guided inquiry learning aims to answer questions posed through a problem [10]. Guided inquiry learning is an active learning that causes teachers and students to jointly create meaningful learning [11]. Guided inquiry learning also provides immediate experience to learners. Students observe and investigate concrete objects directly [12] and teachers act as facilitators [13].

Guided inquiry learning will be more effective when accompanied by Concrete Representational Abstract sequence [14]. The CRA sequence invites students to go through concrete, representational, and abstract stages [15]. The CRA sequence involves a manipulative object at a concrete stage, using images at the representation stage, and using numbers only in the abstract stage [16].If learners do not show mastery at the representation stage then learning returns to a concrete stage, if learners do not show mastery at the abstract stage then the learning goes back to the representation stage.

In support of guided inquiry learning with CRA sequences it is necessary to develop mathematics learning instruments [17]. Learning instruments developed consist of lesson plan and student worksheet. Student worksheets based on guided inquiry can improve student's ability to solve problems because they contain questions that attract students to come up the solutions of problems. The development of student worksheets based on guided inquiry also reflects the 
implementation of K13, where students develop scientific thought in finding concepts and solving problems [18].

Based on the existing problems and supported by the opinion of the experts, the formulation of the problem in this research is how the validity and practicality of the mathematic learning instruments. While the purpose of this study is to produce learning tools that are valid and practical.

\section{METHODS}

This type of research is Research and Development (R\&D). The development model used in this research is the plomp model. The plomp development stage includes (1) preliminary research, (2) prototyping phase, and (3) assessment phase.

Research development in this study is only up to the second stage of product development. Based on the above development research, the development of learning instruments consist of lesson plan and student worksheet based on guided inquiry using CRA sequence for junior high school student grade 8 which tested in Junior high school number one IV Koto in second semester of academic year 2017/2018.

The feasibility of developed learning instruments is assessed by measuring the validity and practicality of the device. Instruments used include validation sheet, student response questionnaire, and teacher response questionnaire. Validation sheet is used to assess the components of worksheet in terms of content, construct, linguistic, and graphic. The questionnaire aims to determine the practicalities level of learning instruments during the learning process. The instruments declared valid if obtaining average expert assessment result > 2.4 [19]. A questionnaire response of students and teachers is said to be practical if practicality value $\geqslant 61 \%$ [20].

\section{RESULT AND DISCUSSION}

\section{A. Analysis of Validation Results}

Devices have been developed and validated by 5 experts. They are 3 mathematicians, 1 Indonesian expert, and 1 educational technologist. Based on the results of the validation of these experts can be known the feasibility of the developed product. The feasibility of this product is based on the average score of the scoring results of the five experts. The average results of expert and category assessment of each product can be seen in table I.

TABLE I. VALIDATION RESULT

\begin{tabular}{|l|c|c|}
\hline \multicolumn{1}{|c|}{ Product } & $\begin{array}{c}\text { Average assessment } \\
\text { results }\end{array}$ & category \\
\hline Lesson Plan & 3.32 & Very Valid \\
\hline Student Worksheet & 3.61 & Very Valid \\
\hline
\end{tabular}

Based on the Table I, it is known that the average result of the assessment of lesson plan and student worksheet is in very valid category. This means that the initial product is feasible for use in small group trials. However, the lesson plan and student worksheet can be used after several revisions based on suggestions and input from the expert. Experts who are experts in the field of Indonesian Language provide suggestions to improve spelling and provide a point at the end of each sentence. While the expert who is expert in the field of mathematics provide suggestions to improve the learning objectives that exist in the lesson plan, adjust the student worksheet with the learning model used, and pay attention again the allocation of time with the developed device.

\section{B. Analysis of Small Group Trial Practices}

After obtaining valid, student worksheet trial on small groups. Trials are conducted to determine the practicality of the developed product. Practical data was obtained from questionnaire response given to 6 students. Students are given a questionnaire consisting of low, medium, and high. Before response the questionnaire, students were asked to work on each student worksheet. The category of questionnaire results of student responses on small group trials can be seen in table II.

TABLE II. RESULT OF SMALL GROUP RESPONS

\begin{tabular}{|l|c|c|}
\hline Aspect of assessment & $\begin{array}{c}\text { The value of } \\
\text { practicality }\end{array}$ & Category \\
\hline Student Worksheet & $85.50 \%$ & Practical \\
\hline
\end{tabular}

Based on the table II, it is known that student's responses to student worksheets are in the practical category. The result show that the product developed meets the practical category according to the student's assessment. Notes obtained from students are taken as input to product improvements developed prior to use in field trials. Some students provide notes of typos, obscure language, elusive issues, and unclear images.

\section{Analysis of Field Trial Practicality Results}

The results of revisions of small group trial products were then used in a broader trial of field trials. The data analysis of field trial result includes the analysis of practical data from the teacher and the students. Practical data from the teacher was obtained from a questionnaire of teacher responses given to one mathematics teacher. Before give teacher's response questionnaire, the teacher has taught the class using a learning instrument that the researcher develops.

Practical data from students is obtained from student response questionnaire given to 25 students. Before completing a student response questionnaire, students have learned use the student worksheet that the researcher develops. The categories of questionnaire results of teacher and student response on field trials can be seen in table III. 
TABLE III. R RESULT OF FIELD TEST RESPONS

\begin{tabular}{|l|c|c|}
\hline $\begin{array}{c}\text { Response } \\
\text { Questionnaire }\end{array}$ & $\begin{array}{c}\text { The value of } \\
\text { practicality }\end{array}$ & Category \\
\hline Teacher & $90.62 \%$ & Very Practical \\
\hline Student & $85.50 \%$ & Very Practical \\
\hline
\end{tabular}

Based on the table III, it is known that the developed lesson plan meets the criteria very practical. Assessment is given by students and teachers after the learning process ends. The teacher assesses the lesson plan and student worksheet. Teachers assess the lesson plans and student worksheets that teachers have used. The teacher advises on the order of the material taught in the probability chapter.

\section{CONCLUSION}

Based on the results of research and discussion obtained the following conclusions: 1) learning instruments developed are in the category very valid, 2) learning Instruments that are tested in criteria very practical so feasible use in learning mathematics.

\section{ACKNOWLEDGMENT}

The researchers would like to thank the principals, teachers, and the whole range of Junior High School Number 1 of IV Koto which has provided an opportunity for researchers to conduct research.

\section{REFERENCES}

[1] Akinmola, E.A, "Developing mathematical problem solving ability: a panacea for a sustainable development in the 21st century" in International Journal of Education and Research, Vol.2, pp.1-8, 2016.

[2] Ersoy, Esen, "Problem Solving and its Teaching in Mathematics" Journal of New Horizons in Education - April 2016 Department of Elementary Mathematics Education, Faculty of Education, Ondokuz Mayıs University, Turkey. Vol.6, Issue 2, 2016.

[3] U Sumarmo and H Hendriana, "Penilaian Pembelajaran Matematika". Bandung: PT Rafika Aditama, 2016.

[4] Depdikbud, "PERMENDIKBUD No.58 Th. 2014 tentang Kurikulum 2013 Sekolah Menengah Perrtama/Madrasah Tsanawiyah" [Online].

[5] Himmah, Nurfi Rif'atul, "Profil Pemecahan Masalah Matematika Model Pisa Berdasarkan Kemampuan Matematika Siswa SMA", MATHEdunesa Jurnal. Vol.3, No.5, 2016.

[6] Yustianingsih, R., Syarifuddin, H., dan Yerizon, Y., "Pengembangan Perangkat Pembelajaran Matematika Berbasis Problem Based Learning (PBL) untuk Meningkatkan Kemampuan Pemecahan Masalah Peserta Didik Kelas VIII", JNPM (Jurnal Nasional Pendidikan Matematika) Vol. 1(2), Hal. 258-274,2017.
[7] Kunandar, "Guru Profesional: Implementasi Kurikulum Tingkat Satuan Pendidikan (KTSP) dan Sukses dalam Sertifikasi Guru", Jakarta: Rajawali Press, 2010.

[8] Kuhlthau, C.C, Maniotes, L. K, Caspai, A, "Guided Inquiry:School Libraries in the $21^{\text {st }}$ century, London: Libraries Unlimited, 2007.

[9] Sayyadi, M., A., Muhardjito, "Pengaruh strategi pembelajaran inkuiri terbimbing terhadap kemampuan pemecahan masalah fisika pada materi suhu dan kalor dlihat dari kemampuan awal siswa", Jurnal Inspirasi Pendidikan Universitas Kanjuruhan Malang, Vol. 6, No. 2, pp. 866-874, 2016.

[10] Fry, Kim, "Sparking mathematical inquiry: Integrating literature and history with the mathematics classroom" in practical literacy, Vol. 21, No. 3, october 2016 .

[11] Gialamas, Stephanos, Cherif, Abour; Keller, Sarah; and Hansen, Ann "Using Guided Inquiry in Teaching Mathematical subject" in humanistic Mathematics Network Journal, Issue. 25, Article 11, 2001

[12] Olibie, Eyiuche Ifeoma \& Kate Oge Ezeoba, "Ability and location differences in the effects of guided inquiry on Nigerian students' achievement in social studies curriculum", Journal of Education and Human Development, Vol. 3, No. 4, pp. 335-334, 2014.

[13] Calleja, James, "Teaching Mathematics through Inquiry" in journal of the international society for design and development in education", Vol.3, issue 9, article 30, 2016.

[14] AfriI, Lisa Dwi. Analisis Kemampuan Pemecahan Masalah Matematis Siswa pada Pembelajaran Inkuiri Terbimbing dengan Pendekatan CRA, Math Educa Journal, Vol. 1, No. 1, pp. 25-36, sep. 2017.

[15] Witzel, Bradley, "Using CRA to Teach Algebra to Students with Math Difficulties in Inclusive Settings" in Learning Disabilities: A Contemporary Journal Vol. 3, No.2, pp. 49-60, 2005.

[16] Flores, Margaret M., Hinton, Vanessa M., and Burton, Megan E., "Teaching Problem Solving to Students Receiving Tiered Interventions Using the Concrete-Representational-Abstract Sequence and Schema-Based Instruction" in Preventing School Failure, Vol. 60, No. 4, pp. 345-355, 2016.

[17] Rahmiati, Sari, "Teaching materials dvelopment of student worksheet guided inquiry based on the materials for learning rate of chemical reaction" in proceedings of Academics world $28^{\text {th }}$ Internasional Conference, Tokyo, Japan, 2016.

[18] Siahaan, M., Sahyar, S., Sirait, M., "Development of student activity sheet (worksheet) based on guided inquiry to improve student's critical thinking skills in senior high school"in journal of education and practice, Vol. 8, No. 20, 2017.

[19] Muliyardi, "Pengembangan Media Pembelajaran Matematika Berbasis Komik di Kelas I Sekolah Dasar", Surabaya: UNESA, 2006.unpublished.

[20] Riduwan, "Belajar Mudah Penelitian Untuk Guru, karyawan dan peneliti Pemula", Alfabeta: Bandung, 2010. 